\title{
ISOLATION AND IDENTIFICATION OF ENDOPHYTIC FUNGI FROM TERMINALIA CHEBULA OF EASTERN GHATS, TAMILNADU
}

\author{
RAJESWARI S, REVATHI R, ARVIND PRASANTH D* \\ Department of Microbiology, Medical Microbiology Laboratory, School of Bioscience, Periyar University, Salem - 636 011, Tamil Nadu, \\ India. Email: prasanthviji@gmail.com
}

Received: 03 October 2016, Revised and Accepted: 30 December 2016

\section{ABSTRACT}

Objective: Endophytic fungi live inside the higher plants, apparently without causing any harm to the hosts and its produce the secondary metabolites are potential antimicrobial activity. Terminalia chebula has been used in Ayurveda, Unani, and Homeopathy medicine. In this study, an isolate and identify the endophytic fungi from T. chebula collected from Pachamalai hills of the Eastern Ghats, Tamil Nadu.

Methods: The plant materials were taken and first rinsed in running tap water to remove the dust and the other debris present in it. Segments of approximately $0.5 \mathrm{~cm}$ were cut in sterile lancet blades and surface sterilized by agitating in $70 \%$ ethanol ( $5 \mathrm{~s}$ ), followed by treatment with $4 \%$ NaOCl (90 s) and then rinsed in sterile distilled water (10 s). 36 (leaf, stem and fruit samples) segments from T. chebula plant are processed for the isolation of endophytic fungi.

Results: About 36 segments (12 segments of each part respectively) of the medicinal plant were screened for the isolation of the endophytic fungi. A total of 27 endophytic fungi was isolated and identified from medicinal plant T. chebula. The leaf segments showed a maximum repository for endophytic fungi than the other segments. Among the 27 endophytic fungi, the predominant endophytic fungi isolated belonged to the genera of Alternaria longipes, Curvularia spp., Mucor phoma spp., Aspergillus niger, Aspergillus flavus, and Penicillium spp. In this study, the majority of the fungi belonged to hyaline hyphomycetes.

Conclusion: In this study, conclude that the isolation of endophytic fungi from medicinal plant of T. chebula. To isolate the 27 endophytic fungi produce the novel bioactive compound. However, further studies are required to screen these endophytic fungi for production of novel bioactive compounds.

Keywords: Endophytic fungi, Terminalia chebula, Bioactive compound.

(C) 2017 The Authors. Published by Innovare Academic Sciences Pvt Ltd. This is an open access article under the CC BY license (http://creativecommons. org/licenses/by/4. 0/) DOI: http://dx.doi.org/10.22159/ajpcr.2017.v10i4.15507

\section{INTRODUCTION}

Medicinal plants play a crucial role in providing primary health care to human populations, since the dawn of civilization. The knowledge of medicinal plants has been accumulated from different medicinal systems such as Ayurveda, Unani, and Siddha. In India, it is reported that traditional healers use 2500 plant species and 100 species of plants serve as regular source of medicine. During the last few decades, there has been an increasing interest in the study of these medicinal plants has been witnessed in different parts of the world mainly due to many problems associated with synthetic drugs and with the emergence of multi-drug resistant pathogens [1]. Out of these, 10,000 species are known to be medicine Indian System of Medicine uses around 3000 plant species belonging to more than 1000 genera [2]. Endophytes are microorganisms that are present in living tissue of various plants (root, fruit, stem, seed, leaf, etc.) establishing mutual relationship without apparently any symptom of diseases. These endophytes protect their hosts from infectious agents and adverse conditions by secreting bioactive secondary metabolites.

The endophytic fungi play important physiological and ecological roles in their host life. Recent investigations have been intensified by the potentialities of endophytic fungus strains in production of bioactive metabolites such as taxol, pestaloside, torreyanic acid and enzymes, xylanase, isoflavonoids, and asparagines [3]. Terminalia chebula is a moderate tree used in traditional medicines. It belongs to the family combretaceae. T. chebula (Haritaki) has been extensively used in Ayurveda, Unani, and Homeopathy medicine and has become cynosure of modern medicine due to the wide spectrum of pharmacological activities associated with the biologically active chemicals present in this plant [4].

\section{METHODS}

\section{Collection of plants}

Healthy leaves stem and fruit segments of T. chebula were collected from Pachamalai hills in Eastern Ghats, Tamil Nadu. The plant material was brought to the laboratory in sterile bags and processed immediately to reduce the chances of contamination.

\section{Isolation of endophytic fungi}

The plant materials were taken and first rinsed in running tap water to remove the dust and the other debris present in it. Segments of approximately $0.5 \mathrm{~cm}$ were cut in sterile lancet blades and surface sterilized by agitating in $70 \%$ ethanol ( $5 \mathrm{~s}$ ), followed by treatment with $4 \% \mathrm{NaOCl}(90 \mathrm{~s})$ and then rinsed in sterile distilled water $(10 \mathrm{~s})$. 36 (leaf, stem, and fruit samples) segments from T. chebula plant are processed for the isolation of endophytic fungi. Leaf, stem, and fruit segments were then placed onto Potato dextrose agar (PDA) amended with chloramphenicol $150 \mathrm{mg} / \mathrm{l}$. The Petri dishes were sealed using parafilm and incubated at $28^{\circ} \mathrm{C}$. The fungi that grown out from the tissues was isolated and stocked. The cultures were maintained on PDA slants at $4^{\circ} \mathrm{C}$ for further screening [5]

\section{Identification of endophytic isolates}

The endophytic fungal isolates were identified up to genus level based on the morphological features such as colony morphology, pigmentation, growth pattern, spore structures, and other hyphal characteristics with the help of the standard mycological manuals. The microscopic examination was also done to study their reproductive spores. Cultures which failed to produce spores were grown on different minimal media and incubated for several weeks to months [6]. 
Statistical analysis

Colonization frequency (CF)

To know the endophyte richness, the frequency of fungal endophytes harbored in plant species were calculated by the number of segments colonized by endophyte species divided by a total number of segments examined $\times 100[7]$.

Colonization frequency (CF\%):

$\mathrm{CF}=\frac{\text { No. of individual fungi recorded }}{\text { Total no. of segments screened }} \times 100$

\section{RESULTS}

About 36 segments (12 segments of each part respectively) of the medicinal plant were screened for the isolation of the endophytic fungi. A total of 27 endophytic fungi was isolated and identified from medicinal plant T. chebula. The leaf segments showed a maximum repository for endophytic fungi than the other segments. Among the 27 endophytic fungi, the predominant endophytic fungi isolated belonged to the genera of Alternaria longipes, Curvularia spp., Mucor phoma spp., Aspergillus niger, Aspergillus flavus, and Penicillium spp. Tables 1 and 2 showed the CF value and taxonomic position of endophytic fungi.

The predominant endophytic fungi isolated belonged to the genera of Curvularia spp., A. niger, Mucor spp., Penicillium spp., Phoma spp., and dematiaceous fungi namely Bipolaris spp. Some fungi which did not produce any reproductive structure, as they produced sterile mycelia and in some cases sterile pycnidium were also grouped under mycelia sterilia. These fungi did not sporulate in spite of repeated subculturing

Table 1: Endophytic fungi isolated from the medicinal plant, T. chebula

\begin{tabular}{llll}
\hline Site of location & No. of samples & No. of fungi isolated & CF (\%) \\
\hline Leaves & 12 & 11 & 91 \\
Stems & 12 & 9 & 75 \\
Flowers & 12 & 7 & 58 \\
Total & 36 & 27 & 74.6 \\
\hline
\end{tabular}

T. chebula: Terminalia chebula, CF: Colonization frequency on to sporulating media (PDA, Sabouraud's dextrose agar, and tap water agar) and hence are grouped on mycelia sterilia.

In this study, the majority of the fungi (Table 3) belonged to hyaline hyphomycetes or group of fungi imperfecti or deuteromycetes, except for the genus Bipolaris which belonged to dematiaceous hyphomycetes. Mucor spp. was belonged to zygomycetes and Phoma spp. was belonged to coelomycetes. The colonization frequency was found to be $74.6 \%$.

\section{DISCUSSION}

This study was carried to isolation and identification of endophytic fungi from pachamalai hills of Eastern Ghats, Tamil Nadu. In the study, a total of 27 fungal colonies were isolated from 36 segments. Among the 27 endophytic fungi, the predominant endophytic fungi isolated belonged to the genera of A. longipes, Curvularia spp., M. phoma spp., A. niger, A. flavus, and Penicillium spp. These results were similar to the studies of Dhanalakshmi et al. [8], who isolated Alternaria spp., Aspergillus spp., Bipolaris spp., Exophiala spp., Nigrospora spp., and Penicillium spp. in Moringa oleifera and in another study of Barnabas et al. [9]. This reported Aspergillus spp., as the predominant isolate in the leaves, stem, and roots of M. oleifera. They belonged to hyaline hyphomycetes $40 \%$, coelomycetes are $8.33 \%$, dematiaceous hyphomycetes $29 \%$, zygomycetes $12.5 \%$, and mycelia sterilia $12.5 \%$. These isolated are belonged to hyphomycetes (59.32\%), coelomycetes $(22.03 \%)$, ascomycetes (13.56\%), and sterile mycelium (5.08\%) [10]. The same results are showed the presence of endophytic fungi in Avicennia officinalis, that isolated the endophytic fungi namely reported Aspergillus, Penicillium, Curvularia, Cladosporium, Phoma, and Fusarium species [11].

\section{CONCLUSION}

Medicinal plants are good source for isolation of endophytic fungi that colonize the tissue without causing apparent symptoms. Endophytic organisms have received considerable attention as they are found to protect their hosts against pests, pathogens and even domestic herbivores. In this study, a total of 27 endophytic fungi were isolated from the T. chebula. T. chebula, a well-known medicinal plant contains various chemical compounds. Isolation of endophytic fungi from this plant produces novel bioactive compounds.

Table 2: Taxonomic position of endophytic fungi

\begin{tabular}{lll}
\hline S. No. & Isolated endophytes & Fungal class \\
\hline 1 & Alternaria longipes & Dematiaceous hyphomycetes (deuteromycetes) \\
2 & Curvularia spp. & Dematiaceous hyphomycetes (deuteromycetes) \\
3 & Curvularia lunata & Dematiaceous hyphomycetes (deuteromycetes) \\
4 & Mucor & Zygomycetes \\
5 & Phoma spp. & Coelomycetes \\
6 & Exophiala spp. & Hyaline hyphomycetes (deuteromycetes) \\
7 & Penicillium spp. & Hyaline hyphomycetes (deuteromycetes) \\
8 & Fusarium spp. & Hyaline hyphomycetes \\
9 & Aspergillus flavus & Hyaline hyphomycetes (deuteromycetes) \\
10 & Bipolaris spp. & Dematiaceous hyphomycetes (deuteromycetes) \\
11 & Aspergillus fumigatus & Hyaline hyphomycetes (deuteromycetes) \\
12 & Aspergillus niger & Hyaline hyphomycetes (deuteromycetes) \\
13 & Sterile forms & Mycelia sterilia \\
Total & & \\
\hline
\end{tabular}

Table 3: Percentage of isolated fungal class

\begin{tabular}{lll}
\hline S. No. & Fungal class & Total (\%) \\
\hline 1 & Dematiaceous hyphomycetes & $8(29)$ \\
2 & Hyaline hyphomycetes & $11(40)$ \\
3 & Zygomycetes & $3(11.11)$ \\
4 & Coelomycetes & $2(7.40)$ \\
5 & Mycelia sterilia & $3(11.11)$ \\
\hline
\end{tabular}




\section{REFERENCES}

1. Gritto MJ, Nandagopalan V, Doss A. Ethno-botanical study on the traditional healers in Pachamalai hills of Eastern Ghats, Tamilnadu, South India. J Med Plants Stud 2015;3(2):80-5.

2. Vaidyanathan D, Senthilkumar MS, Sisubalan N, Basha MG. Studies on ethnomedicinal plants used by Malayali Gounder Tribes in Pachamalai of Eastern Ghats, Tamil Nadu, India. Adv Appl Sci Res 2014;5(1):244-53.

3. Dar RA, Rather SA, Mushtaq S, Qazi PH. Purification and characterization of endophytic fungal strains from four different high value medicinal plants of Kashmir valley. Int J Phytopharm 2015;5(1):8-11.

4. Sandhu SS, Kumar S, Aharwal RP. Isolation and identification of endophytic fungi from Ricinus communis Linn. and their antibacterial activity. Int J Res Pharm Chem 2014;4(3):611-8.

5. Shiva Kameshwari MN, Mohana B, Thara Saraswathi KJ. Isolation and identification of endophytic fungi from Urginea indica, a medicinal plant from diverse regions of South India. Int J Latest Res Sci Technol 2015;4(1):75-80
6. Anitha D, Vijaya T, Pragathi D, Reddy NV, Mouli KC, Venkateswarulu N, et al. Isolation and characterization of endophytic fungi from endemic medicinal plants of Tirumala hills. Int J Life Sci Biotechnol Pharm Res 2013;2(3):367-73.

7. Divya CR, Sharada MS, Ashwini V. Isolation and identification of endophytic fungi in Trigonella foenum-graceum L. and their antibacterial activity. Imp J Interdiscip Res 2016;2(9):516-21.

8. Dhanalakshmi R, Umamaheswari S, Sugandhi P, Prasanth DA. Biodiversity of the endophytic fungi isolated from Moringa oleifera of Yercaud hills. Int J Pharm Sci Res 2013;4(3):1064-8.

9. Barnabas J, Murthy S, Jagdeesh S. Antimicrobial properties of endophytic fungi isolated from Cynodon dactylon and Moringa oleifera. Int J Biol Pharm Res 2013;4(2):98-104.

10. Tenguria RK, Firodiya A. Occurrence of endophytic fungi in leaves of medicinal plants from Central Region of Madhya Pradesh, India. World J Pharm Pharm Sci 2015;4(11):1921-34.

11. Job N, Manomi S, Philip R. Isolation and characterization of endophytic fungi from Avicennia officinalis. Int $\mathrm{J}$ Res Biomed Biotechnol 2015;5(1):4-8. 